\title{
Staphylococcus aureus-An Additional Parameter of Bathing Water Quality for Crowded Urban Beaches
}

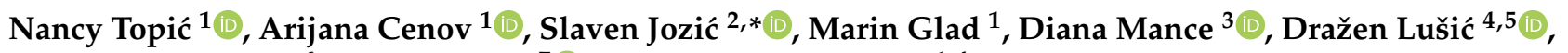 \\ Damir Kapetanović ${ }^{6}$, Davor Mance ${ }^{7}$ (D) and Darija Vukić Lušić ${ }^{1,4}$ \\ 1 Department of Environmental Health, Teaching Institute of Public Health of Primorje-Gorski Kotar County, \\ Krešimirova 52a, 51000 Rijeka, Croatia; nancy.topic@gmail.com (N.T.); arijana.cenov@zzjzpgz.hr (A.C.); \\ marin.glad@zzjzpgz.hr (M.G.); darija.vukic-lusic@zzjzpgz.hr (D.V.L.) \\ 2 Laboratory of Microbiology, Institute of Oceanography and Fisheries, P.O. Box 500, 21000 Split, Croatia \\ 3 Department of Physics, University of Rijeka, Radmile Matejčić 2, 51000 Rijeka, Croatia; diana.mance@uniri.hr \\ 4 Department of Environmental Health, Faculty of Medicine, University of Rijeka, Braće Branchetta 20, \\ 51000 Rijeka, Croatia; drazen.lusic@medri.uniri.hr \\ 5 Faculty of Health Studies, University of Rijeka, Viktora Cara Emina 5, 51000 Rijeka, Croatia \\ 6 Ruđer Bošković Institute, Division for Marine and Environmental Research, Bijenička Cesta 54, \\ 10000 Zagreb, Croatia; kada@irb.hr \\ 7 Faculty of Economics, University of Rijeka, Ivana Filipovića 4, 51000 Rijeka, Croatia; davor.mance@efri.hr \\ * Correspondence: sjozic@izor.hr; Tel.: +385-(0)-2140-8052
}

Citation: Topić, N.; Cenov, A.; Jozić, S.; Glad, M.; Mance, D.; Lušić, D.; Kapetanović, D.; Mance, D.; Vukić Lušić, D. Staphylococcus aureus-An Additional Parameter of Bathing Water Quality for Crowded Urban Beaches. Int. J. Environ. Res. Public Health 2021, 18, 5234. https:// doi.org/10.3390/ijerph18105234

Academic Editor: Paul B. Tchounwou

Received: 27 April 2021

Accepted: 11 May 2021

Published: 14 May 2021

Publisher's Note: MDPI stays neutral with regard to jurisdictional claims in published maps and institutional affiliations.

Copyright: (c) 2021 by the authors. Licensee MDPI, Basel, Switzerland. This article is an open access article distributed under the terms and conditions of the Creative Commons Attribution (CC BY) license (https:// creativecommons.org/licenses/by/ $4.0 /)$.

\begin{abstract}
During the last years, the report of the occurrence of waterborne disease symptoms related to non-enteric pathogens has increased, without any record of higher levels of indicator bacteria (Escherichia coli and intestinal enterococci). Therefore, the use of current indicators is not always adequate when assessing the overall potential health risk and the inclusion of additional parameters needs to be examined. This paper reports on the incidence and levels of Staphylococcus aureus at 258 locations in Primorje-Gorski Kotar County (Croatia) recorded by official bathing water quality monitoring, as well as supplemental monitoring carried out at the two most frequented beaches in the City of Rijeka. The number of bathers was found to be the main factor affecting $S$. aureus levels $(\mathrm{r}=0.321, p<0.05)$. The share of $S$. aureus positive samples from the official monitoring was significantly lower, when compared to the share of samples from supplemental monitoring $(2.2 \%$ and $36.3 \%$, respectively; $p<0.01$ ). Besides the number of bathers, one of the main reasons is likely the higher sampling frequency. No correlation was found between S. aureus levels and the indicator bacteria. The results indicate that the determination of S. aureus and increased sampling frequency is recommended for overcrowded beaches.
\end{abstract}

Keywords: bathing water quality; crowded beaches; fecal indicator bacteria; Staphylococcus aureus

\section{Introduction}

The management of bathing waters in the European Union is regulated by Bathing Water Directive 2006/7/EC (BWD) [1]. Unlike the first edition of the Directive, 76/160/EEZ, which had defined a large set of microbiological, chemical, and physical parameters that bathing water had to meet [2], a new Directive defines only two fecal indicator bacteria (FIB), Escherichia coli and intestinal enterococci, as the parameters in routine monitoring of coastal bathing water quality. According to BWD, the European Commission is required to review the current Directive, no later than 2020, with particular reference to World Health Organization (WHO) recommendations [1]. After a thorough analysis of available scientific research, WHO concluded that there is currently no scientifically substantiated basis for the introduction of new parameters for microbiological monitoring of bathing water quality. Therefore, the WHO recommended that the use of current indicators should be continued [3]. This recommendation is based on the results of the most relevant studies discussed in the report, where the relationship between FIB levels and incidence of the 
most commonly reported illnesses, such as gastrointestinal illness and skin symptoms, was studied and recorded.

Nonetheless, there is a significant number of studies reporting on the incidence of waterborne diseases associated to bathing, whereby FIB levels did not indicate a risk of non-enteric bacterial infections [4,5]. In a review by Korajkic et al. [6], the absence of a correlation between observed illness and FIB levels was reported in seven studies out of 17 for enterococci, and four out of six studies for E. coli.

Since it is obvious that the correlation of indicator bacteria with particular pathogens and/or illness occurrence is still being questioned, and the enumeration of current indicators may be insufficient to assess the risk of non-enteric pathogens $[7,8]$, some bacteria such as Staphylococcus aureus are suggested as potential additional parameters for monitoring of coastal bathing water quality $[7,9,10]$.

S. aureus is considered one of the most resistant non-sporogenic bacteria, with the ability to survive high temperatures, drying, extreme $\mathrm{pH}$, high salinity, antibiotics, and disinfection treatments [11-14]. These bacteria are normal commensals of the human nasopharynx, anterior nares, perineum, and skin [15]. Most of the time, these bacteria cause no problems or result in relatively minor skin infections, but occasionally the infections can turn deadly and cause serious health issues. It is estimated that $20-40 \%$ of the human population transmits this opportunistic pathogen [16-18]. Besides humans, domestic animals $[19,20]$ and birds [21] are considered as an important reservoir of this bacteria. High levels of $S$. aureus shed by bathers (adults and children) of about $10^{5}-10^{6} \mathrm{CFU} /$ person during $15 \mathrm{~min}[22,23]$ and a positive correlation with skin, ear, and respiratory infections in seawater [24], suggest that this opportunistic pathogen is a possible additional parameter to be considered in monitoring the seawater quality of crowded beaches. This is supported by higher adaptability of $S$. aureus to seawater conditions because of its high survival capacity at higher salinities, compared to FIB [25].

The main goal of this paper is to assess whether the inclusion of S. aureus in official (routine) monitoring of bathing water quality should be considered on the basis of the results of $S$. aureus incidence and levels in seawater under different environmental conditions, such as abiotic factors, beach load/number of bathers, and also FIB levels.

\section{Materials and Methods}

\subsection{Study Area and Sampling}

During the 2017 bathing season, national official (routine) monitoring of bathing water quality in Primorje-Gorski Kotar County (Croatia) was carried out fortnightly, from mid-May to the end of September (10 samples per site per season). Samples were taken at 258 official bathing sites. Besides the mandatory indicator bacteria (E. coli and intestinal enterococci), an additional parameter, S. aureus, was included.

Additional, supplemental monitoring was carried out at four official bathing sites located along the two most frequented urban beaches of the county, in the west part of the city of Rijeka, namely, Ploče beach (east-PE and west-PW bathing sites) and Kantrida beach (east-KE and west-KW bathing sites). Unlike official monitoring, sampling was performed every day, including the weekends, with 248 samples taken during the period 1 July to 31 August 2017.

Kantrida beach is a 270-m long urban pebble beach with many beach facilities (coffee bars, showers, slides, benches, parking areas, and ancillary facilities) (Figure 1). Near the beach, there is an area characterized by numerous fresh water springs. The most important one is Cerovica spring, which significantly affects the quality of the seawater. Abundant rainfall causes short-term contamination of the sea, which increases the health risk for bathers [26]. 


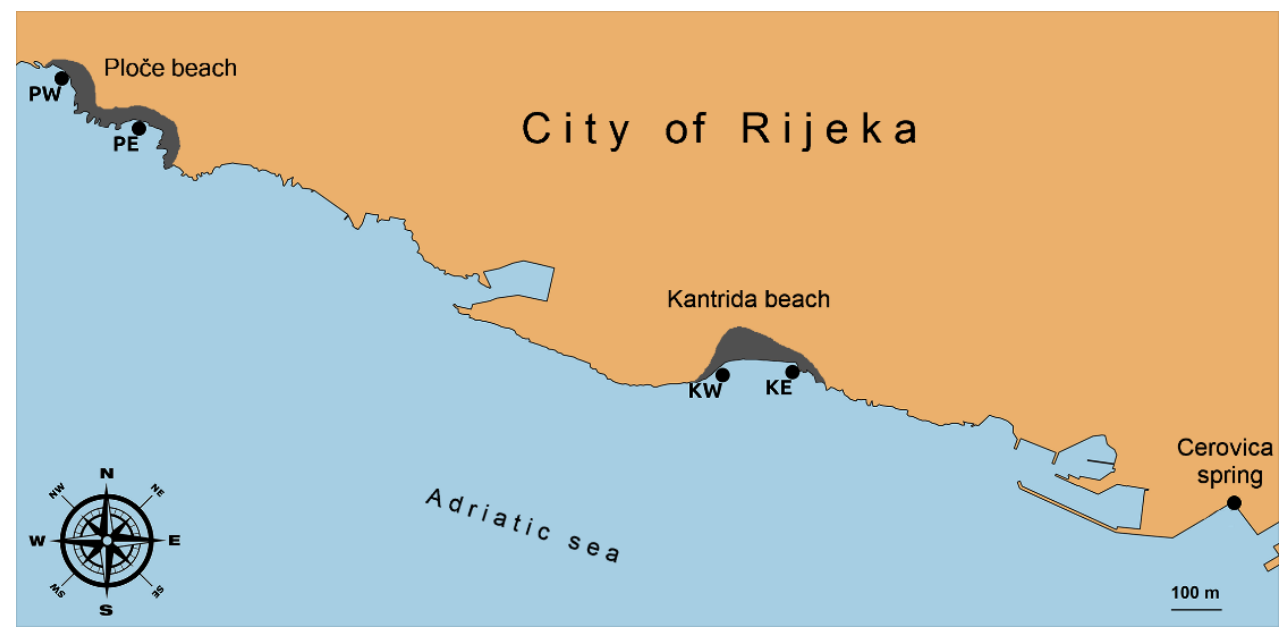

Figure 1. Kantrida (east-KE, west-KW) and Ploče (east-PE, west-PW) beaches and sampling sites.

Ploče Beach is a 330-m long urban pebble beach. It is located in front of the Kantrida Swimming Pool Complex, a sport, recreation, and entertainment complex (Figure 1). Ploče beach has been awarded Blue Flag status, an international recognition of exceptional cleanliness, quality, and tidiness of a beach.

Sampling for both the official and supplemental monitoring program was performed during the morning hours. The samples were taken by applying the aseptic technique, $30 \mathrm{~cm}$ below the surface, in water with a minimum depth of $1 \mathrm{~m}$. All samples were processed as soon as possible, on the same day. In total, 2867 seawater samples were obtained during regular and supplemental monitoring, and tested for S. aureus. Sampling reports were produced throughout the official and supplemental monitoring program, including the sample identification number of each location, the sampling date and time, and air and sea water temperature. Beach load data (number of bathers/children in diapers/dogs/seagulls) for each sampling event at each sampling site were determined by visual observation at the time of sampling. This was done by the students, by direct counting, or subsequent processing of the photographed situations. For ease of interpretation, the beach load data were subsequently classified into categories: $N(0)=$ category " 0 ", $N(1-50)=$ "1", $N(50-100)=" 2 ", N(100-150)=" 3 ", N(150-200)=" 4 ", N(>200)=“ 5 "$.

\subsection{Sample Analysis}

\subsubsection{Microbiological Analysis}

Laboratory analysis was based on the detection and quantification of E. coli and intestinal enterococci, along with S. aureus as the additional parameter. All microbiological parameters were determined using a membrane filtration technique, the temperature modified HRN EN ISO 9308-1:2014 method [27,28] for E. coli, HRN EN ISO 7899-2:2000 for intestinal enterococci and the method described by Standard methods 23rd. Ed 2017. 9213 B for S. aureus [29]. In brief, for each parameter, the samples $(10 \mathrm{~mL}$ and $100 \mathrm{~mL})$ were filtered through $47 \mathrm{~mm}$ in diameter cellulose nitrate membranes, $0.45 \mu \mathrm{m}$ pore size for E. coli and intestinal enterococci, and $0.22 \mu \mathrm{m}$ for S. aureus. After filtration, the funnels were rinsed twice with sterile deionized water, and the membranes were then transferred to Chromogenic Coliform Agar (CCA) for E. coli, Slanetz \& Bartley agar for intestinal enterococci and Baird-Parker agar for S. aureus.

CCA was incubated for $4 \mathrm{~h}$ at $36 \pm 2{ }^{\circ} \mathrm{C}$, followed by $20 \mathrm{~h}$ at $44 \pm 0.5^{\circ} \mathrm{C}$. All dark-blue to violet colonies were counted as confirmed E. coli.

After incubation on Slanetz \& Bartley agar at $36{ }^{\circ} \mathrm{C} \pm 2{ }^{\circ} \mathrm{C}$ for $44 \pm 4 \mathrm{~h}$, the membranes used for the enumeration of intestinal enterococci were transferred to prewarmed $\left(44^{\circ} \mathrm{C}\right)$ Bile Aesculin Azide Agar and incubated at $44 \pm 0.5^{\circ} \mathrm{C}$ for $2 \mathrm{~h}$. All pink, red, or brown 
colonies that developed a brown or black halo on Bile Aesculin Azide Agar were counted as confirmed enterococci.

Baird-Parker agar was incubated at $35 \pm 0.5^{\circ} \mathrm{C}$ for $48 \pm 4 \mathrm{~h}$. Staphylococci typically form slate-grey to jet-black smooth, entire colonies. The presence of presumptive S. aureus colonies was observed by a zone of egg yolk clearing when the membranes were raised from the medium. Depending on the total number of colonies on the membrane, all colonies (if there were less than 10 colonies) or at least 10 differentiated presumptive colonies from each membrane were verified by coagulase production and catalase reaction. All coagulase and catalase positive colonies were counted as confirmed S. aureus.

\subsubsection{Physical/Chemical Analysis}

Air and seawater temperature were measured in situ, using a centigrade mercury scale thermometer (scale 0.1). The $\mathrm{pH}$ values and salinity were determined at the laboratory, using a $\mathrm{pH}$ meter and a conductometer, respectively. Likewise, seawater turbidity was estimated at the laboratory using an optical instrument-turbidimeter (nephelometric turbidity examination).

\subsubsection{Data Analysis}

Normality of data was tested using the Kolmogorov-Smirnov test. Since the data, for all measured parameters, failed the expectation of Gaussian distribution, the following non-parametric tests were performed: Spearman's rank order correlation, Chi-square test, Wilcoxon matched pairs test, Mann-Whitney U test, and Kruskal-Wallis H test. Principal component analysis (PCA) was performed to identify components that explain the major variation within data. For presentation of the results, descriptive statistical methods were applied (relative frequency, median, interquartile range-IQR), as well as graphs and tables. Statistical analysis of the data was performed using the Microsoft Excel Statistic Package (Redmond, WA, USA), Statistica 13 (Stat. Soft. Inc., Tulsa, OK, USA, SAD) and Canoco version 5 (http:/ / www.canoco5.com/ (accessed on 07 May 2021)). The results were interpreted at a statistical significance level of under 0.05 .

\section{Results}

\subsection{Official vs. Supplemental Monitoring}

The results revealed a higher share of samples positive for $S$. aureus for the supplemental monitoring program compared to national official monitoring (Chi2 test, $p<0.01$ ). During official monitoring, only $2.2 \%$ of samples were positive for S. aureus $(57 / 2619)$, while as many as $36.3 \%(90 / 248)$ of the supplemental monitoring samples were positive. Considering the results obtained for four sampling locations where supplemental monitoring was carried out, only $5 \%(1 / 20)$ of the official monitoring samples were positive during the same sampling period (1 July to 31 August 2017). The results of the Mann-Whitney $\mathrm{U}$ test indicate a significant difference $(\mathrm{Z}=2.98 ; p<0.01)$ in the medians of the $S$. aureus values in positive samples during official (median 2 CFU/100 mL, IQR 1-4 CFU/100 mL) and supplemental (median 4 CFU / $100 \mathrm{~mL}$, IQR 2-10 CFU/100 mL) monitoring.

Several groups can be discerned from the PCA biplot. The first consists of the number of bathers and children, air and seawater temperature and S. aureus, while the second group consists of E. coli and intestinal enterococci (Figure 2). Spearman's correlation analysis supports the results of PCA analysis, showing a weak but statistically significant positive correlation between $S$. aureus and sea temperature $(\mathrm{rs}=0.243 ; p<0.05)$, air temperature ( $\mathrm{rs}=0.147 ; p<0.05)$, number of bathers ( $\mathrm{rs}=0.321 ; p<0.05)$, and number of children in diapers ( $r s=0.203 ; p<0.05)$. No significant correlation between $S$. aureus and FIB levels was found (Table 1). 


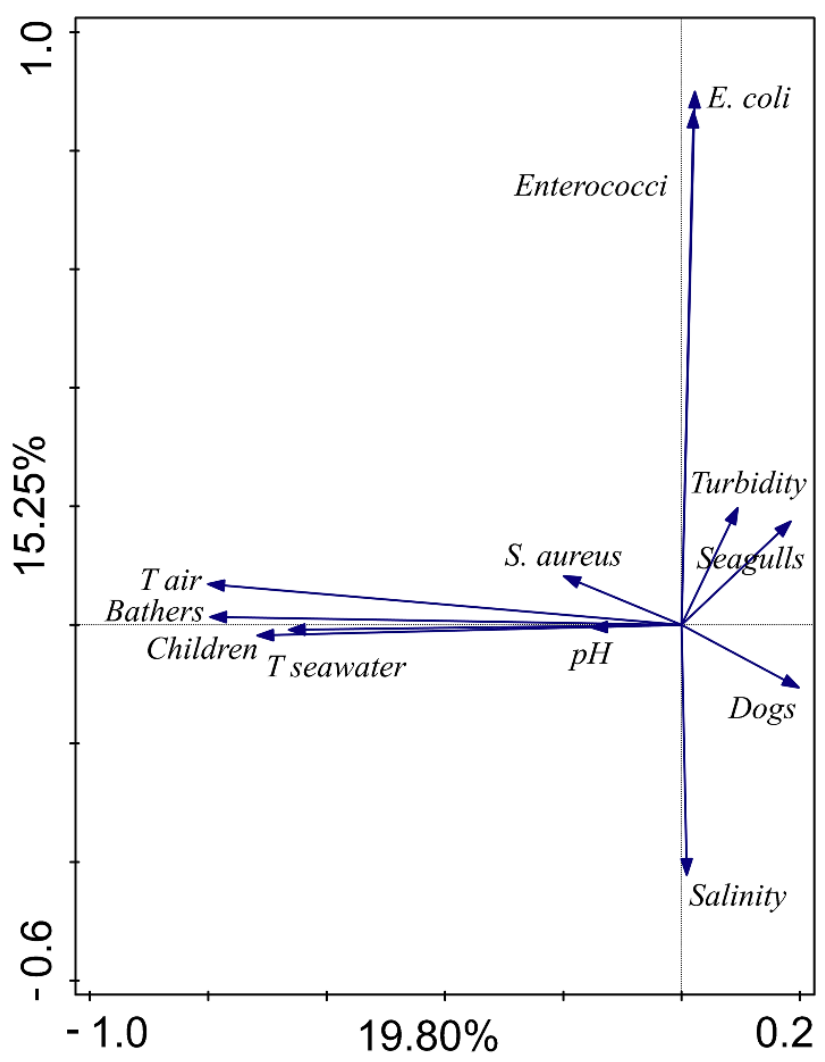

Figure 2. PCA analysis biplot.

Table 1. Spearman correlation coefficients between the examined variables (supplemental monitoring data). Statistically significant correlations $(p<0.05)$ are highlighted in bold.

\begin{tabular}{|c|c|c|c|c|c|c|c|c|c|c|c|}
\hline Variables & 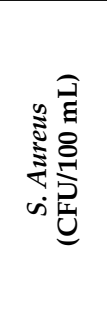 & 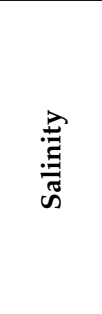 & $\frac{1}{2}$ & 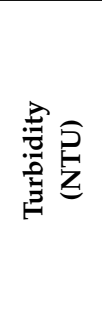 & 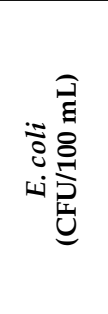 & 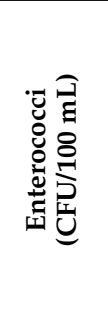 & 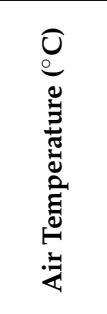 & 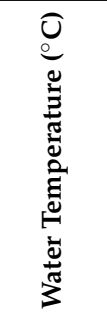 & 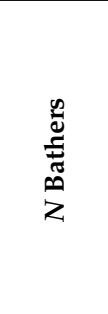 & 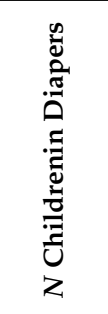 & $\begin{array}{l}\infty \\
\text { o } \\
0^{\circ} \\
z\end{array}$ \\
\hline Salinity & -0.033 & & & & & & & & & & \\
\hline $\mathrm{pH}$ & 0.048 & -0.020 & & & & & & & & & \\
\hline Turbidity (NTU) & 0.046 & -0.353 & -0.025 & & & & & & & & \\
\hline E. coli (CFU / $100 \mathrm{~mL})$ & 0.084 & -0.395 & -0.094 & 0.211 & & & & & & & \\
\hline Enterococci (CFU/100 mL) & 0.088 & -0.379 & -0.057 & 0.208 & 0.695 & & & & & & \\
\hline Air temperature $\left({ }^{\circ} \mathrm{C}\right)$ & 0.147 & 0.111 & 0.052 & 0.008 & -0.273 & -0.276 & & & & & \\
\hline Water temperature $\left({ }^{\circ} \mathrm{C}\right)$ & 0.243 & 0.066 & 0.274 & -0.252 & -0.319 & -0.307 & 0.416 & & & & \\
\hline$N$ bathers & 0.321 & 0.131 & 0.081 & -0.226 & -0.136 & -0.161 & 0.367 & 0.498 & & & \\
\hline$N$ children in diapers & 0.203 & 0.117 & 0.014 & -0.130 & -0.220 & -0.176 & 0.355 & 0.395 & 0.673 & & \\
\hline$N$ dogs & -0.065 & -0.286 & -0.066 & 0.287 & 0.294 & 0.264 & -0.341 & -0.419 & -0.390 & -0.261 & \\
\hline$N$ seagulls & 0.035 & -0.208 & 0.039 & 0.221 & 0.316 & 0.216 & -0.166 & -0.221 & -0.229 & -0.382 & 0.252 \\
\hline
\end{tabular}

\subsection{Kantrida vs. Ploče Beaches}

Although located in the west part of the city, on a small stretch of about $900 \mathrm{~m}$, Kantrida and Ploče beaches showed significant differences in the percentage of samples positive for $S$. aureus (Chi2 test, $p<0.01$ ), and also between the concentrations of $S$. aureus in positive samples (The Mann-Whitney test, $\mathrm{Z}=-3.73 ; p<0.01$ ). Considering the results of supplemental monitoring carried out on Kantrida and Ploče beaches, the percentage of samples positive for S. aureus was 49.2\% (61/124) and 22.4\% (29/124), respectively. The 
median value of the positive results obtained during supplemental monitoring was higher on Kantrida beach than on Ploče beach (Table 2). No statistically significant difference between the concentrations of $S$. aureus in positive samples was found between two sampling locations of the same beach, i.e., Kantrida East and West $(Z=0.533, p=0.593)$ and Ploče East and West $(Z=0.044 ; p=0.965)$.

Table 2. Values of parameters measured at Kantrida and Ploče beaches.

\begin{tabular}{ccc}
\hline \multirow{2}{*}{ Parameter } & \multicolumn{2}{c}{ Median (IQR 25-75) } \\
\cline { 2 - 3 } & Ploče & Kantrida \\
\hline S. aureus $(\mathrm{CFU} / 100 \mathrm{~mL})$ & $2(1-3)$ & $6(2-14)$ \\
E. coli $(\mathrm{CFU} / 100 \mathrm{~mL})$ & $7(3-22)$ & $29.5(11.5-77)$ \\
Intestinal enterococci & $7(3-18)$ & $18(10-35)$ \\
$(\mathrm{CFU} / 100 \mathrm{~mL})$ & $36.1(34.2-37.2)$ & $35.0(33.0-36.7)$ \\
Salinity & $25.0(23.0-25.0)$ & $24.0(23.0-25.0)$ \\
Water temperature $\left({ }^{\circ} \mathrm{C}\right)$ & $26.0(25.0-28.0)$ & $26.0(25.0-28.0)$ \\
Air temperature $\left({ }^{\circ} \mathrm{C}\right)$ & $0.50(0.38-0.7)$ & $0.62(0.49-0.85)$ \\
Turbidity $(\mathrm{NTU})$ & $8.0(7.9-8.0)$ & $8.0(7.9-8.0)$ \\
pH & &
\end{tabular}

Overall, of the total number of supplemental monitoring samples positive for $S$. aureus, $76.6 \%$ had a concentration of $\leq 10 \mathrm{CFU} / 100 \mathrm{~mL}$ (Figure 3). Out of all sample positive for S. aureus, in 18 samples (20\%), the count of at least one of FIB was lower than the count of S. aureus, and in four samples, no FIB was detected.

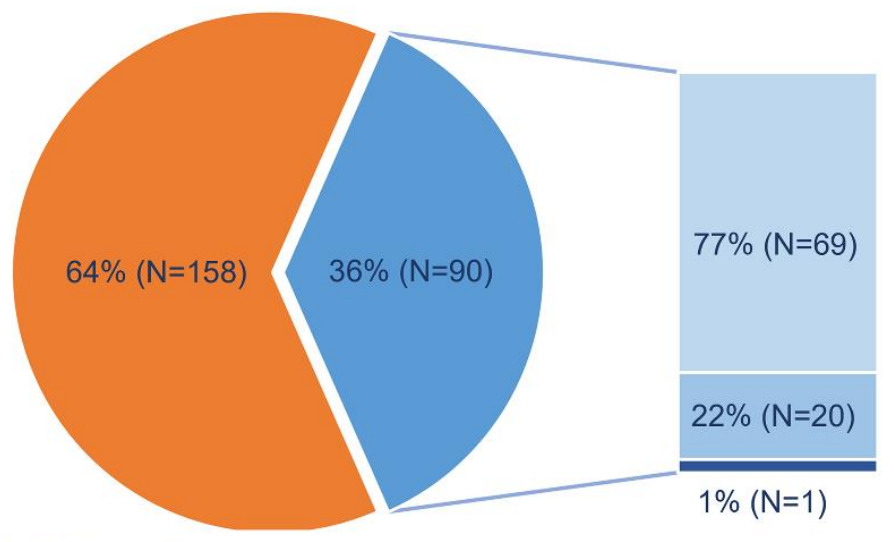

\footnotetext{
S. aureus negative

- S. aureus positive

$1-10$ CFU/100 mL

$11-100 \mathrm{CFU} / 100 \mathrm{~mL}$

- > $100 \mathrm{CFU} / 100 \mathrm{~mL}$
}

Figure 3. Percentage of $S$. aureus positive seawater samples, based on S. aureus level.

Apart from the differences in the concentration of $S$. aureus, a difference in the concentrations of FIB was observed between the two beaches. The results of the Mann-Whitney U test indicate a significant difference in the concentration of routine fecal indicators, $E$. coli $(Z=6.67 ; p<0.01)$ and intestinal enterococci $(Z=4.78 ; p<0.01)$, between the beaches. Both, $E$. coli and intestinal enterococci concentrations were higher on Kantrida beach than on Ploče beach (Table 2).

Bathing water quality based on FIB data obtained during supplemental monitoring, and assessed using 95th percentile of all data, as defined by BWD, also showed better water quality on Kantrida beach when compared to the water quality on Ploče beach. Both sites on Ploče beach (PE and PW) were of "excellent" water quality, while water quality at one site on Kantrida beach (KW) was of "good" quality (Figure 4). 
$\square$. coli $\quad$ Intestinal enterococci

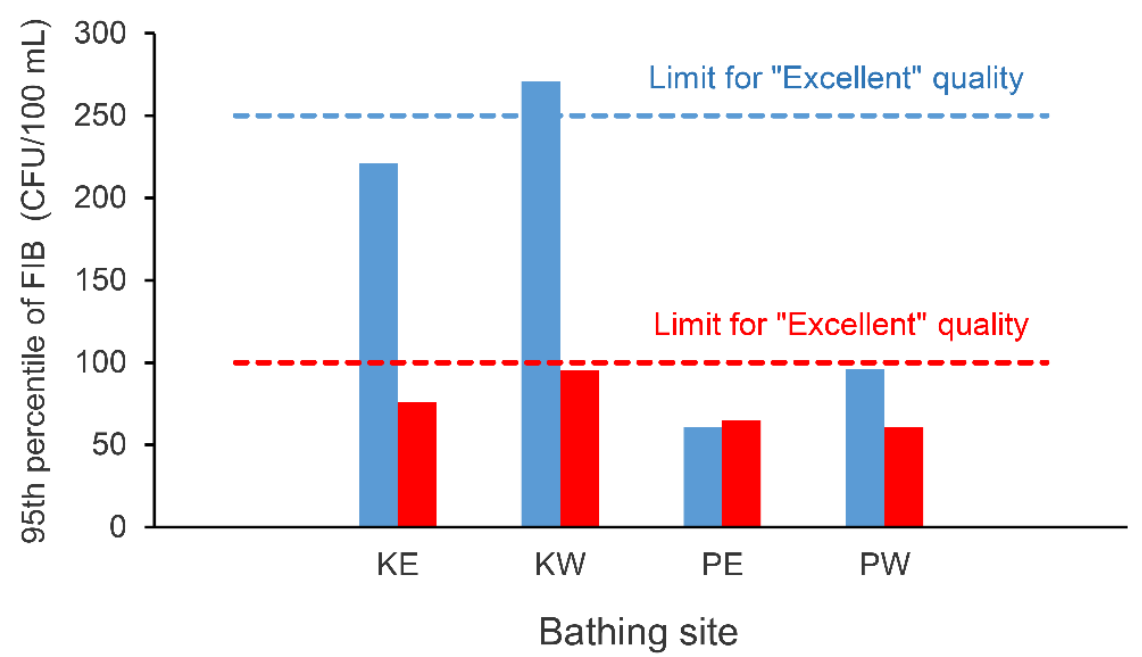

Figure 4. The 95th percentile of FIB data obtained by supplemental monitoring.

The Wilcoxon matched pairs test showed a significant difference $(p<0.05)$ in salinity and turbidity between Kantrida and Ploče beach, while no significant difference in temperature was recorded between these locations (Table 2).

During the 14 days of supplemental monitoring in 2017, the number of bathers at Kantrida beach was immense $\left(\mathrm{N}_{\text {bathers }}>200\right.$; category $=" 5$ "), especially on the west part of the beach. At Ploče beach, the highest recorded category was " 4 " ( $\left.\mathrm{N}_{\text {bathers }}=150-200\right)$. The seagulls at Kantrida beach were classified into category " 0 " on 63 events, and 61 into category " 1 ", while at Ploče beach, 112 events were classified as " 0 " and only 12 as category "1" (Chi2-test, $p<0.01)$. Considering the witnessed number of dogs, there was only one event of category " 1 " at Kantrida beach, while all others were classified into category " 0 ". Regarding children in diapers, 148 events ( 53 on Kantrida and 95 on Ploče) belonged to category " 1 ", and 16 (Kantrida) to category " 2 ". All other events belonged to category " 0 ".

\section{Discussion}

The share of S. aureus positive samples at Kantrida and Ploče beaches from the official monitoring program was significantly lower (5\%) compared to the supplemental monitoring program $(36.3 \%)$. One of the main reasons is likely sampling frequency. The samples obtained from official monitoring of these two beaches were collected fortnightly, while the supplemental monitoring program sampling was performed on a daily basis, including weekends. With such a high sampling frequency, there is a higher probability of recording seawater contamination events. This is supported by the difference between official and supplemental monitoring as regards the share of FIB positive samples at Kantrida and Ploče beaches. That is, the share of samples that were positive for $E$. coli and enterococci taken at these beaches for official monitoring (biweekly sampling) was 71.8 and 70.0\% respectively, while for supplemental monitoring (daily sampling), the share was 96.0 and $90.0 \%$, respectively. This indicates that the sampling frequency could affect the probability of recording bathing water contamination events. Moreover, low sampling frequency has been recognized as the main cause of misclassification of bathing water sites [30]. According to the WHO assessment, an increase in sampling frequency from 10 samples per site per season to 20 would reduce misclassification from about $22 \%$ to about $14 \%$ [30]. Furthermore, the results showed a higher share of $S$. aureus positive samples on Kantrida Beach (49.2\%) compared to $22.4 \%$ on Ploče Beach. At the same time, the number of bathers on the beaches indicated greater pressure on Kantrida Beach. It could be assumed that, in addition to higher sampling frequency, the pressure exerted by more bathers also accounted for the higher share of $S$. aureus positive samples, suggesting that bathers are a possible source 
of $S$. aureus contamination. This is supported by the share of $S$. aureus positive samples on Kantrida and Ploče beaches ( $36.3 \%$ or 90 out of 248 samples), compared to the data obtained by the official national monitoring program at all bathing sites in the county $(2.2 \%$ or 57 out of 2619 samples). A plausible reason is the difference in beach load, i.e., number of bathers. Kantrida and Ploče are two of the most frequented beaches of the county and considerably more loaded with bathers than other beaches. A significant correlation between the presence of $S$. aureus in seawater and the number of bathers in the coastal environment has been shown by Cheung et al. [31] and Yoshpe-Purer and Golderman [10], who reported a significantly higher incidence of $S$. aureus in Mediterranean coastal waters during the peak bathing period at the most frequented beaches (91\%) compared to the less frequented ones $(49.5 \%)$.

Bathers were confirmed as the possible main source of $S$. aureus by a relatively weak but statistically significant positive correlation between $S$. aureus counts and the number of bathers ( $\mathrm{rs}=0.321 ; p<0.05)$. Higher levels of $S$. aureus are probably due to the higher number of bathers. Similar findings were recorded by Šolić and Krstulović [32], who noted that the highest concentrations were found on the extremely crowded beaches of Split (Croatia). Other studies also found a significant correlation between S. aureus levels in seawater and the number of bathers determined by observation at the time of sampling [20,33,34].

An analysis of the results of supplemental monitoring revealed a positive correlation between S. aureus counts, seawater and air temperature, number of bathers, and number of children in diapers (Table 1). Since the variations in water temperature were relatively low $\left(2{ }^{\circ} \mathrm{C}\right)$ (Table 2), temperature could not affect the differences in bacterial counts considerably. It is very likely that the only causal relationship is that between the number of bathers and $S$. aureus in seawater. Other correlations are likely artefacts, without causal relationship. In other words, during sunny periods, both air temperature and seawater temperature increase, causing favorable meteorological conditions that attract more beach goers to the beaches, and consequently more children in diapers. That means that temperature did not affect the levels of $S$. aureus directly but indirectly by attracting a larger numbers of bathers to the beaches. Goodwin et al. [20] also reported a positive correlation between $S$. aureus and seawater temperature but since they did not examine the relationship between temperature and the number of bathers, the data is insufficient to conclude on whether this is an actual correlation or not.

A primary study of $S$. aureus in avian droppings proved that bird droppings can be an important reservoir of this pathogen [21]. Cragg and Clayton [35] reported that S. aureus is one of the commonest bacteria in the fecal flora of seagulls. In addition to birds, domestic animals, including dogs, can also carry this opportunistic pathogen $[19,36]$. Hence, beaches with more seagulls and dogs may be considered as those with a higher risk of S. aureus contamination. Since no correlation between S. aureus and number of seagulls and dogs at the beach was found in this study, seagulls and dogs can be excluded as likely sources of this bacteria on the studied beaches.

Although some studies recorded a significant correlation between S. aureus and FIB for moderate and extremely polluted areas [32,37], this study did not show a significant correlation between these two parameters. Other studies also reported the absence of any correlation between FIB and S. aureus on highly frequented beaches. A staphylococcal impetigo outbreak in the very popular and frequently visited tourism resort of Vodice in Croatia (July of 2015, in the midst of the bathing season) was not accompanied by increased FIB levels. In $25 \%$ of the samples taken from beaches in the Vodice area during and after the outbreak, S. aureus counts in seawater were $>150 \mathrm{CFU} / 100 \mathrm{~mL}$, while bathing quality was excellent, with very low or undetectable FIB levels [38]. In a study carried out in Egyptian coastal waters, $35 \%$ of bathing water samples exceeded the established guideline values for S. aureus, without any of indicator bacteria being detected [33].

Unlike S. aureus, both indicator bacteria, E. coli and intestinal enterococci, correlated negatively with the number of bathers. This could indicate that FIB at these sites may not 
have originated primarily from bathers but from other plausible sources such as coastal springs, seagulls, and dogs, while $S$. aureus originates from non-fecal sources predominantly shed from the skin and possibly anterior nares of bathers, as reported by Elmir et al. [22].

Furthermore, in addition to attracting more people to the beach, warm and sunny periods undoubtedly resulted in a higher reduction of indicator bacteria counts in seawater. FIB concentration is greatly influenced by the weather and environmental conditions [32,39,40]. It is well-known that an unfavorable marine environment, particularly solar radiation, temperature, and salinity, have a negative effect on allochthones bacteria survival, reducing culturability of FIB in a very short period of exposure [41-44], considerably more intense than the culturability of S. aureus [32]. A greater resistance of S. aureus to marine conditions, and consequently longer survival compared to FIB, is a result of better tolerance for higher salinity [25]. Lower enterococci levels compared to $S$. aureus were recorded in a study by Enns, et al. [7]. This was attributed to a combination of the different levels shed by humans coupled with possible higher sensitivity to solar radiation. Better resistance to environmental factors might be attributed to the clustered structure of $S$. aureus, which reduces the area exposed to environmental factors, solar radiation in particular.

The awareness of bathers also contributes to the negative correlation between FIB counts and the number of bathers. Beachgoers are most likely even more aware of the importance of the quality of bathing water and they regularly check the quality of bathing water before going to the beach. They avoid visiting a beach when the water is of poorer quality. This assumption is supported by a significant increase of web access statistics (unique Hit Counters by location) for web application "Sea bathing water quality on beaches", from 13,881 in 2009 to 56,119 for Primorje-Gorski Kotar County in the 2019 bathing season [45].

Unlike S. aureus, both indicator bacteria were significantly positively correlated with the number of seagulls and dogs. Besides dog faces and seagull droppings being possible direct sources of fecal contamination, weather conditions likely contributed to higher FIB counts. Generally, cloudy weather and rainy periods contribute to lower FIB reduction in seawater, by lower solar radiation, lower air and seawater temperature and salinity. All these parameters correlated negatively with FIB counts. Since no correlation between the number of bathers and FIB bacteria was found, numerous coastal and underwater springs that intensify after rain events, are the most likely source of fecal contamination at these beaches. This is confirmed by lower salinity and sea temperature, and higher turbidity recorded at Kantrida beach, with pronounced variations in salinity values, compared to Ploče beach. Thus, the levels of E. coli and intestinal enterococci were higher at Kantrida beach. Mance et al. [46] also reported coastal springs on Kantrida Beach as occasional sources of higher microbial load.

Finally, based on the assessment of bathing water quality at bathing sites included in supplemental monitoring, it could be concluded that FIB are not always a good indicator of $S$. aureus incidence and levels. Consequently, bathing waters can pass the FIB standard but still have high counts of $S$. aureus. This is supported by the fact that all bathing sites, where supplemental monitoring was carried out, were assessed as having excellent or good quality (Figure 4). It means that there was a low chance of the occurrence of pathogenic microorganisms and low risk of waterborne diseases associated to bathing. Furthermore, in as many as $20 \%$ of samples positive for S. aureus, the levels of at least one FIB were lower than the levels of S. aureus. Additionally, in a few S. aureus positive samples, no FIB was detected. Unfortunately, there is no data on possible bathing-related infections reported by bathers on these beaches, so it cannot be argued whether the recorded levels of $S$. aureus resulted in an increased incidence of staphylococcal infections. In general, there is a lack of studies addressing the relationship between recorded $S$. aureus counts in bathing water and the occurrence of symptoms of staphylococcal infection. One of the reasons for this could be a general failure of beach-goers to report some of the symptoms due to their mild nature and short duration [47]. The main finding by the retrospective epidemiological monitoring study conducted by Charoenca and Fujioka [48] was the strong association between marine 
water contact and staphylococcal infections. Water analyzes were performed subsequently, so it was not possible to determine $S$. aureus levels in the water at the time of exposure, but $S$. aureus isolates recovered from skin and water had similar antibiotic sensitivity patterns and phage typing, supporting the conclusion that marine waters were the transmission medium for staphylococcal infections.

Furthermore, available scientific literature does not provide evidence for a limit value based on dose-response relation for exposure to $S$. aureus in bathing water [49]. In some studies, authors used the value of $100 \mathrm{CFU} / 100 \mathrm{~mL}$, proposed by Favero et al. [50] as the permissible maximum for swimming pool water. Considering that the study included staphylococci in general, not just $S$. aureus, the proposed value cannot simply be applied to $S$. aureus. Therefore, further studies are needed to examine which levels of $S$. aureus in bathing water may lead to the onset of symptoms of staphylococcal infections and to determine appropriate limit values. A faster procedure and more selective method, without additional confirmatory tests, would also contribute to better and more reliable data as well as to more timely results.

However, it seems that there is a justified need for the inclusion of additional parameters, such as S. aureus, in the monitoring of bathing water. In addition, regional specificities should also be taken into account when revising the Directive. The EU is a vast area with diverse geographical, climatic, and hydrological characteristics that may influence the occurrence and persistence of certain allochthones microorganisms, such as $S$. aureus, and naturally occurring microorganisms, such as P. aeruginosa and Vibrio species, as well as natural phenomena such as cyanobacterial blooms. This may affect the suitability of the current indicators as the only indicators of the microbiological quality of bathing water. For this reason, the Directive should allow Member States to include additional, regionally specific parameters in their national bathing water quality management legislation. This would significantly improve the protection of human health, which is the main purpose of the Directive.

\section{Conclusions}

The correlation between the number of bathers on a beach and $S$. aureus counts in the seawater samples indicates that the contamination of Kantrida and Ploče beaches by $S$. aureus is likely due to bathers. When compared to other, less-loaded beaches in the county, the incidence and levels of $S$. aureus were significantly higher at these urban beaches, very often overloaded with bathers. This was probably not only due to the higher number of bathers, as a main source of $S$. aureus, but also to significantly higher sampling frequency, which increases the probability of recording pollution. No correlation was found between $S$. aureus and fecal indicator bacteria (FIB), E. coli and intestinal enterococci, thus indicating that $S$. aureus was not of fecal origin and that the current indicator bacteria are not always an adequate indicator of health risk.

Based on its incidence and levels recorded in seawater in this study, the possibility of including $S$. aureus as an additional parameter in official (routine) monitoring of bathing water quality at excessively loaded urban beaches is justified, regardless of the microbiological seawater quality based on FIB levels. Sampling frequency at these beaches should also be increased. Additional research is required in order to obtain a better understanding of the issue and document relevant discussions. In addition to conducting epidemiological studies regarding the correlation of $S$. aureus in bathing water with the incidence of staphylococcal infections, current sampling frequency should be reconsidered, and guideline values of $S$. aureus need to be proposed.

Author Contributions: Conceptualization, D.V.L., S.J. and A.C.; methodology, A.C., N.T. and M.G.; validation, D.V.L. and A.C.; formal analysis, D.M. (Diana Mance), D.M. (Davor Mance), and M.G.; investigation, N.T., D.L., D.M. (Diana Mance), and D.M. (Davor Mance); resources, D.K.; writingoriginal draft preparation, N.T., D.L. and D.K.; writing—review and editing, S.J. and D.V.L.; visualization, M.G., D.L., and D.M. (Davor Mance); supervision, D.V.L. and S.J.; project administration, 
D.L.; funding acquisition, D.V.L. and D.M. (Diana Mance) All authors have read and agreed to the published version of the manuscript.

Funding: This research was partially funded by the University of Rijeka, grant number uniri-biomed18-292 and uniri-pr-prirod 19-24).

Institutional Review Board Statement: Not applicable.

Informed Consent Statement: Not applicable.

Data Availability Statement: The data presented in this study are available on request from the corresponding author. The data are not publicly available due to the fact that large portion derives from the official Croatian national monitoring. In that regard, raw data about the quality of the bathing seawater are not published on the official platform, and only the categories of bathing water quality (excellent, good, satisfactory and poor) are issued. The reason for that is inadequate level of education of the public for interpretation of gathered raw bacterial counts in seawater.

Acknowledgments: The authors would like to thank the students of the Environmental Health course of study, University of Rijeka, for their valuable help during the sampling and sanitary assessment of the studied beaches.

Conflicts of Interest: The authors declare no conflict of interest. The funders had no role in the design of the study; in the collection, analyses, or interpretation of data; in the writing of the manuscript, or in the decision to publish the results.

\section{References}

1. The Council of the European Communities. Council Directive 76/160/EEC of 8 December 1975 Concerning the Quality of Bathing Water; European Communities: Brussels, Belgium, 1975.

2. The European Parliament and the Council of the European Union. Directive 2006/7/EC of 15 February 2006 Concerning the Management of Bathing Water Quality and Repealing Directive 76/160/EEC.; European Union: Brussels, Belgium, 2006.

3. World Health Organization (WHO). WHO Recommendations on Scientific, Analytical and Epidemiological Developments Relevant to the Parameters for Bathing Water Quality in the Bathing Water Directive (2006/7/EC). 2018. Available online: https://circabc.europa.eu/d/d/workspace/SpacesStore/9e89152c-7cfe-4391-9bcf-c173519e8181/WHO\%20 Recommendations\%20on\%20EC\%20BWD.pdf (accessed on 20 April 2020).

4. King, S.; Exley, J.; Winpenny, E.; Alves, L.; Henham, M.L.; Larkin, J. The Health Risks of Bathing in Recreational Waters: A Rapid Evidence Assessment of Water Quality and Gastrointestinal Illness. Rand Health Q. 2015, 4, 5.

5. Papastergiou, P.; Mouchtouri, V.; Pinaka, O.; Katsiaflaka, A.; Rachiotis, G.; Hadjichristodoulou, C. Elevated bathing-associated disease risks despite certified water quality: A cohort study. Int. J. Environ. Res. Public Health 2012, 9, 1548-1565. [CrossRef] [PubMed]

6. Korajkic, A.; McMinn, B.R.; Harwood, V.J. Relationships between Microbial Indicators and Pathogens in Recreational Water Settings. Int. J. Environ. Res. Public Health 2018, 15, 2842. [CrossRef] [PubMed]

7. Enns, A.A.; Vogel, L.J.; Abdelzaher, A.M.; Solo-Gabriele, H.M.; Plano, L.R.W.; Gidley, M.L.; Phillips, M.C.; Klaus, J.S.; Piggot, A.M.; Feng, Z.; et al. Spatial and temporal variation in indicator microbe sampling is influential in beach management decisions. Water Res. 2012, 46, 2237-2246. [CrossRef] [PubMed]

8. Zabed, H.; Suely, A.; Faruq, G.; Sahu, J.N. Water quality assessment of an unusual ritual well in Bangladesh and impact of mass bathing on this quality. Sci. Total Environ. 2014, 472, 363-369. [CrossRef] [PubMed]

9. Curiel-Ayala, F.; Quiñones-Ramírez, E.I.; Pless, R.C.; González-Jasso, E. Comparative studies on Enterococcus, Clostridium perfringens and Staphylococcus aureus as quality indicators in tropical seawater at a Pacific Mexican beach resort. Mar. Pollut. Bull. 2012, 64, 2193-2198. [CrossRef] [PubMed]

10. Yoshpe-Purer, Y.; Golderman, S. Occurrence of Staphylococcus aureus and Pseudomonas aeruginosa in Israeli coastal water. Appl. Environ. Microbiol. 1987, 53, 1138-1141. [CrossRef] [PubMed]

11. Bruins, M.J.; Juffer, P.; Wolfhagen, M.J.; Ruijs, G.J. Salt tolerance of methicillin-resistant and methicillin-susceptible Staphylococcus aureus. J. Clin. Microbiol. 2007, 45, 682-683. [CrossRef]

12. Chambers, H.F.; Deleo, F.R. Waves of resistance: Staphylococcus aureus in the antibiotic era. Nat. Rev. Microbiol. 2009, 7, 629-641. [CrossRef]

13. Food Standards Australia New Zealand (FSANZ) Staphylococcus aureus-Food Standards Australia. Available online: https: / / www.foodstandards.gov.au/publications/Documents/Staphylococcus\%20aureus.pdf (accessed on 15 November 2019).

14. Taheri, N.; Ardebili, A.; Amouzandeh-Nobaveh, A.; Ghaznavi-Rad, E. Frequency of antiseptic resistance among Staphylococcus aureus and coagulase-negative Staphylococci isolated from a University hospital in central Iran. Oman Med. J. 2016, 31, 426-432. [CrossRef]

15. Kloos, W.E.; Bannerman, T.L. Update on clinical significance of coagulase-negative staphylococci. Clin. Microbiol. Rev. 1994, 7, 117-140. [CrossRef] [PubMed] 
16. Al-Zu'bi, E.; Bdour, S.; Shehabi, A.A. Antibiotic resistance patterns of mecA-positive Staphylococcus aureus isolates from clinical specimens and nasal carriage. Microb. Drug Resist. 2004, 10, 321-324. [CrossRef]

17. Kluytmans, J.A.; Wertheim, H.F. Nasal carriage of Staphylococcus aureus and prevention of nosocomial infections. Infection 2005, 33, 3-8. [CrossRef]

18. Kuehnert, M.J.; Kruszon-Moran, D.; Hill, H.A.; McQuillan, G.; McAllister, S.K.; Fosheim, G.; McDougal, L.K.; Chaitram, J.; Jensen, B.; Fridkin, S.K.; et al. Prevalence of Staphylococcus aureus nasal colonization in the United States, 2001-2002. J. Infect. Dis. 2006, 193, 172-179. [CrossRef] [PubMed]

19. Boost, M.V.; O’Donoghue, M.M.; James, A. Prevalence of Staphylococcus aureus carriage among dogs and their owners. Epidemiol. Infect. 2008, 136, 953-964. [CrossRef] [PubMed]

20. Goodwin, K.D.; McNay, M.; Cao, Y.; Ebentier, D.; Madison, M.; Griffith, J.F. A multi-beach study of Staphylococcus aureus, MRSA, and enterococci in seawater and beach sand. Water Res. 2012, 46, 4195-4207. [CrossRef]

21. Gilmore, S. Characterization and Isolation of Fecal Indicator Bacteria, Staphylococcus aureus, and Methicillin-Resistant Staphylococcus aureus from Pacific Northwest Marine Beach Samples. Master's Thesis, University of Washington, Seattle, WA, USA, 2012.

22. Elmir, S.M.; Wright, M.E.; Abdelzaher, A.; Solo-Gabriele, H.M.; Fleming, L.E.; Miller, G.; Rybolowik, M.; Peter Shih, M.T.; Pillai, S.P.; Cooper, J.A.; et al. Quantitative evaluation of bacteria released by bathers in a marine water. Water Res. 2007, 41, 3-10. [CrossRef]

23. Plano, L.R.W.; Garza, A.C.; Shibata, T.; Elmir, S.M.; Kish, J.; Sinigalliano, C.D.; Gidley, M.L.; Miller, G.; Withum, K.; Fleming, L.E.; et al. Shedding of Staphylococcus aureus and methicillin-resistant Staphylococcus aureus from adult and pediatric bathers in marine waters. BMC Microbiol. 2011, 11. [CrossRef] [PubMed]

24. Cheung, W.H.; Chang, K.C.; Hung, R.P.; Kleevens, J.W. Health effects of beach water pollution in Hong Kong. Epidemiol. Infect. 1990, 105, 139-162. [CrossRef]

25. Gabutti, G.; De Donno, A.; Bagordo, F.; Montagna, M.T. Comparative Survival of Faecal and Human Contaminants and Use of Staphylococcus aureus as an Effective Indicator of Human Pollution. Mar. Pollut. Bull. 2000, 40, 697-700. [CrossRef]

26. Vukić Lušić, D.; Lušić, D.; Pešut, D.; Mićović, V.; Glad, M.; Bilajac, L.; Peršić, V. Evaluation of equivalence between different methods for enumeration of fecal indicator bacteria before and after adoption of the new Bathing Water Directive and risk assessment of pollution. Mar. Pollut. Bull. 2013, 73, 252-257. [CrossRef] [PubMed]

27. Jozić, S.; Vukić Lušić, D. Report on Validation of Temperature Modified ISO 9308-1:2014 Method for the Enumeration of Escherichia coli in Bathing Water Samples in Croatia; Institute of Oceanography and Fisheries: Croatia, Balkan, 2018.

28. Jozić, S.; Vukić Lušić, D.; Ordulj, M.; Frlan, E.; Cenov, A.; Diković, S.; Kauzlarić, V.; Fiorido Đurković, L.; Stilinović Totić, J.; Ivšinović, D.; et al. Performance characteristics of the temperature-modified ISO 9308-1 method for the enumeration of Escherichia coli in marine and inland bathing waters. Mar. Pollut. Bull. 2018, 135, 150-158. [CrossRef]

29. Baird, R.; Bridgewater, L. Standard Methods for the Examination of Water and Wastewater, 23rd ed.; American Public Health Association: Washington, DC, USA, 2017.

30. World Health Organization (WHO). Guidelines for Safe Recreational Water Environments Volume 1: Coastal and Fresh Waters; World Health Organization: Switzerland, Geneva, 2003.

31. Cheung, W.H.; Chang, K.C.; Hung, R.P. Variations in microbial indicator densities in beach waters and health-related assessment of bathing water quality. Epidemiol. Infect. 1991, 106, 329-344. [CrossRef] [PubMed]

32. Šolić, M.; Krstulović, N. Presence and survival of Staphylococcus aureus in the coastal area of Split (Adriatic Sea). Mar. Pollut. Bull. 1994, 28, 696-700. [CrossRef]

33. El-Shenawy, M.A. Staphylococcus aureus and fecal indicators in Egyptian coastal waters of Agaba gulf, Suez gulf and Red sea. Egypt. J. Aquat. Res. 2004, 31, 113-124.

34. Charoenca, N.; Fujioka, R.S. Assessment of Staphylococcus bacteria in Hawaii's marine recreational waters. Water Sci. Technol. 1993, 27, 283-289. [CrossRef]

35. Cragg, J.; Clayton, Y.M. Bacterial and fungal flora of seagull droppings in Jersey. J. Clin. Pathol. 1971, 24, 317-319. [CrossRef] [PubMed]

36. Biberstein, E.L.; Jang, S.S.; Hirsh, D.C. Species distribution of coagulase-positive staphylococci in animals. J. Clin. Microbiol. 1984, 19, 610-615. [CrossRef]

37. Efstratiou, M.A.; Mavridou, A.; Richardson, S.C.; Papadakis, J.A. Correlation of bacterial indicator organisms with Salmonella spp., Staphylococcus aureus and Candida albicans in sea water. Lett. Appl. Microbiol. 1998, 26, 342-346. [CrossRef]

38. Bujas, L.; Unić Klarin, B. Sea quality on the beaches of the Šibenik-Knin County in 2015. In XXII Working Meeting of County Public Health Institutes, Administrative Departments and Institutes Responsible for Environmental Protection, Physical Planning, Construction, Communal Economy, Sustainable Development and Maritime Affairs of the Adriatic Area; Ministry of Environmental Protection and Energy: Croatia, Balkan, 2016.

39. Krstulović, N.; Šolić, M. Die-off rate of Staphylococcus aureus in sea-water. In Proceedings of the Rapport du XXXIVE Congrès de la CIESM, Valletta, Malta, 23 March-1 April 1995; Commission Internationale pour L'exploration Scientifique de la mer Méditerranée (CIESM): Monaco, 1995; p. 158.

40. Vukić Lušić, D.; Kranjčević, L.; Mačešić, S.; Lušić, D.; Jozić, S.; Linšak, Z.; Bilajac, L.; Grbčić, L.; Bilajac, N. Temporal variations analyses and predictive modeling of microbiological seawater quality. Water Res. 2017, 119, 160-170. [CrossRef] 
41. Davies-Colley, R.J.; Bell, R.G.; Donnison, A.M. Sunlight inactivation of enterococci and fecal coliforms in sewage effluent diluted in seawater. Appl. Environ. Microbiol. 1994, 60, 2049-2058. [CrossRef] [PubMed]

42. Fujioka, R.S.; Hashimoto, H.H.; Siwak, E.B.; Young, R.H. Effect of sunlight on survival of indicator bacteria in seawater. Appl. Environ. Microbiol. 1981, 41, 690-696. [CrossRef] [PubMed]

43. Jozić, S.; Morović, M.; Šolić, M.; Krstulović, N.; Ordulj, M. Effect of solar radiation, temperature and salinity on the survival of two different strains of Escherichia coli. Fresenius Environ. Bull. 2014, 23, 1852-1859.

44. Sinton, L.W.; Davies-Colley, R.J.; Bell, R.G. Inactivation of enterococci and fecal coliforms from sewage and meatworks effluents in seawater chambers. Appl. Environ. Microbiol. 1994, 60, 2040-2048. [CrossRef]

45. Institute of Oceanography and Fisheries (IOF) Sea Bathing Water Quality in Croatia. Available online: http://baltazar.izor.hr/ plazepub/kakvoca_detalji10 (accessed on 7 September 2020).

46. Mance, D.; Mance, D.; Vukić Lušić, D. Marine pollution differentiation with stable isotopes of groundwater. Pomorstvo 2018, 31, 80-87. [CrossRef]

47. Esiobu, N.; Green, M.; Echeverry, A.; Bonilla, T.D.; Stinson, C.M.; Hartz, A.; Rogerson, A.; Mc Corquodale, D.S. High numbers of Staphylococcus aureus at three bathing beaches in South Florida. Int. J. Environ. Res. Public Health 2013, 23, 46-57. [CrossRef]

48. Chareonca, N.; Fujioka, R.S. Association of staphylococcal skin infections and swimming. Water Sci. Technol. 1995, 31, 11-17. [CrossRef]

49. Schets, F.M.; van der Berg, H.H.J.L.; Lynch, G.; de Rijk, S.; de Roda Husman, A.M.; Schijven, J.H. Evaluation of water quality guidelines for public swimming ponds. Environ. Int. 2020, 137. [CrossRef] [PubMed]

50. Favero, M.S.; Drake, C.H.; Randall, G.B. Use of staphylococci as indicators of swimming pool pollution. Public Health Rep. 1964, 79, 61-70. [CrossRef] [PubMed] 